\title{
Methods for analysis of dietary fibre - advantage and limitations*
}

\author{
Bach Knudsen K.E, Helle Nygaard Johansen and Vibe Glitsø
}

\author{
Danish Institute of Animal Sciences, Department of Nutrition, \\ Research Centre Foulum, P.O. Box 50 \\ $D K-8830$ Tjele, Denmark
}

(Received 25 April 1997; accepted 15 May 1997)

\begin{abstract}
The two main approaches for the determination of dietary fibre (DF) in food and feedstuffs are the enzymatic- and nonenzymatic-gravimetric AOAC (Association of Official Analytical Chemists) procedures and the enzymatic-chemical Englyst and Uppsala procedures. The main analytical problems which have been shown to influence the performance of the enzymatic-gravimetric AOAC procedures are: variable starch removal, too high final phosphate buffer concentration, and hence variable ash content of gravimetric residues, problems with residual nitrogen detcrmination, filtration problems of viscous and desugared fruit samples, and variable blank values. Standardisation and improvements of the methods have gradually improved the performance of the gravimetric procedures to acceptable levels. The cnzymatic-chemical methods with gas-liquid chromatography (GLC), high performance liquid chromatography (HPLC) or colorimetry as endpoint determination are generally more complex, involve more steps and require, for the GLC and HPLC methods, more advance cquipment than the gravimetric procedures. The efficiency of starch removal, the hydrolytic conditions for acid hydrolysis of DF polysaccharides, factorial corrections for hydrolytic losses of sugars and laboratory expertise are identified as factors influencing the reproducibility of the methods. Modifications and optimisation of the various steps and the build-up of expertise in laboratories participating in the collaborative trials have improved the reproducibility of the enzymatic-chemical methods to a level similar to that of the enzymatic-gravimetric AOAC methods. Technical problems which may introduce crrors in the determination of DF with all methods are incomplete precipitation in $80 \%(\mathrm{v} / \mathrm{v})$ ethanol, impurities in bactcrial amyloglucosidases resulting in depolymcrisation and potential losses of DF polysaccharides. A recent BCR Reference Material Study indicate that the various DF methods give comparable results for cereal based
\end{abstract}

* Part of this paper was presented at the Symposium: Dietary fibre - chemical composition and biological action, 24-25 April 1997, Radzików, Poland 
materials when appropriate corrections are made for lignin and resistant starch. The same was the case with full fat soya. It is concluded that the techniques for measuring DF are as reproducible as other analytical methods for feed and food labelling and for research. The choice of analytical method depends therefore primarily on the purpose of the analytical work.

KEY WORDS: dietary fibre, analysis

\section{INTRODUCTION}

The need for appropriate analytical methods for the detcrmination of dietary fibre (DF) in food-and feedstuffs is apparent. It is well recognised that DF is an important component of the diets for humans and animals and numerous studies have documented important gastrointestinal and metabolic effects of fibre-rich diets. Furthermore, dietary guidelines in human nutrition advocate increasing the consumption of plant foods. This have led to the demand for reproducible analytical DF methods for control and labelling as well as for nutritional research. Unfortunately, however, the lack of consensus on the definition of DF and the wide range of methods, which do not measure the same dietary entities, have led to inconsistent and confusing data.

The crude fibre method, invented in the middle of the last century, and the neutral detergent fibre (NDF) method, based on the pionering work of Van Soest, have been used earlier to determine the DF value in food- and feedstuffs (Henneberg and Stohmann, 1859; Van Soest, 1963; Van Soest and Wine, 1967). Both methods, however, have their limitations. In the crude fibre method only a small and variable fraction of the total DF is measured, while the water-soluble NSP and water-insoluble pectic substances are lost in the NDF procedure (Bailey and Ulyatt, 1970; Reichert, 1981; Carre and Brillouet, 1986). Moreover, starch and protein may contaminate the NDF residue (Theander and $\AA$ man, 1980).

Over the last two decades there has been a rapid growth in the development of robust and reproducible DF methods. The two main approaches are the enzymatic or non-enzymatic gravimetric AOAC (Association of Official Analytical Chemists) procedures and the enzymatic-chemical Englyst and Uppsala procedures. In the first approach, all non-fibre components are removed from the sample by selective extraction and enzymatic degradation and the residue weighed. The second approach is to measure the dietary fibre constituents directly after extraction of low-molecular weight sugars, enzymatic removal of starch, acid hydrolysis of DF polysaccharides and determination of their monosaccharide residues by gas-liquid chromatography (GLC), high-performance liquid chromatography (HPLC) or colorimetry. These methods were in most cases developed for the analysis of foodstuffs but they can also be applied to feedstuffs. 
The present summary will primarily deal with advantage and limitations of the enzymatic-gravimetric and enzymatic-chemical DF methods commonly in use.

\section{ENZYMATIC-GRAVIMETRIC METHODS}

The original AOAC enzymatic-gravimetric method for the determination of total dietary fibre (TDF) was developed on basis of the joint experience of Asp et al. (1992). The origins of these methods can be tracked back to the biochemical approach of measuring the indigestible residues in human foods introduced by Williams and Olmsted in the 1930s, (1935) and to the work of Hellendrom and collegues (1975). These methods use enzymes to remove the digestible components, which was considered more physiological than extraction with chemical reagents as used in the detergent method.

The main steps in the AOAC procedure (Prosky et al., 1988) and the recent modification proposed by Lee et al. (1992) are outlined in Table 1. Briefly, the procedure consists of the following steps: (a) weighing of $-1 \mathrm{~g}$ in a beaker, (b) incubation with enzymes to remove starch and protein, (c) precipitation of soluble polymers with four volumes of ethanol, (d) quantitative transfer of sample to a pre-weighed crucible, (e) filtration, (f) weighing of the dry crucible and $(\mathrm{g})$ correction for ash and protein in residues. Blanks are carried through the procedure in parallel. In the modification of Lee et al. (1992) the phosphate

TABLE 1

Main steps of the original and modified enzymatic-gravimetric AOAC methods

\begin{tabular}{lll}
\hline & $\begin{array}{l}\text { AOAC original } \\
\text { Prosky et al. (1988) }\end{array}$ & $\begin{array}{l}\text { AOAC modified } \\
\text { Lee et al. (1992) }\end{array}$ \\
\hline $\begin{array}{l}\text { Sample } \\
\text { Buffer }\end{array}$ & $\sim 1 \mathrm{~g}$ & $\sim 1 \mathrm{~g}$ \\
Enzyme step 1 & Na-phosphate pH 6 & MESTRIS pH 8.2 \\
pH adjustment & permamyl $100^{\circ} \mathrm{C}, 15-30 \mathrm{~min}$ & lermamyl $95-100^{\circ} \mathrm{C}, 35 \mathrm{~min}$ \\
Enzyme step 2 & Protease $60^{\circ} \mathrm{C}, 30 \mathrm{~min}$ & Protease $60^{\circ} \mathrm{C}, 30 \mathrm{~min}$ \\
pH adjustment & pH 4.0-4.6 & pH $4.1-4.7$ \\
Enzyme step 3 & Amyloglucosidase $60^{\circ} \mathrm{C}$, & Amyloglucosidase $60^{\circ} \mathrm{C}$, \\
& 30 min & 30 min \\
Volume of 96\% EtOH & & \\
required to precipitage & & \\
soluble DF & $280 \mathrm{ml}$ & $225 \mathrm{ml}$ \\
Filtering aid & Celite 545 & $\mathrm{Celite}$ \\
Protein correction & $\mathrm{N} \mathrm{x} 6.25$ & $\mathrm{~N} \mathrm{x} 6.25$ \\
Ash corrcction & Incincration $525^{\circ} \mathrm{C}$ & Incincration $525^{\circ} \mathrm{C}$ \\
\hline
\end{tabular}


buffer is replaced with a MES/TRIS (2(N-morpholino) ethanesulphonic acid/tris hydroxymethyl amino-methane) buffer, one of the $\mathrm{pH}$ adjustment is eliminated and the total volume is reduced.

\section{Starch removal}

Starch is removed by simultaneous gelatinisation in a water bath at $100^{\circ} \mathrm{C}$ and incubation with heat-stable $x$-amylase (Termamyl). This step is followed by a amyloglucosidase treatment to completely degrade the malto-oligosaccharides to glucose. Although the incubation with heat-stable $\alpha$-amylase in combination with gelatinisation is very efficient, retrograded amylose, formed during food processing, will not be removed by Termamyl but requires solubilisation with either $2 \mathrm{~mol} / 1$ of potassium hydroxide or dimethylsulphoxide (DMSO). This step is not included in the official AOAC procedure, hence resistant starch is measured as DF. Because of the relatively short incubation time, it is important to grind the samples to particles $<0.5 \mathrm{~mm}$. Too large particles have been found to result in variable and insufficient starch removal (Prosky et al., 1984).

\section{Protein correction}

The samples can not be completely depleted for protein by the protease treatment and it is therefore necessary to correct for residual protein by the factor $\mathrm{N} \times 6.25$. The error introduced by applying the arbitrary conversion factor of $\mathrm{N} \times 6.25$ are insignificant in most cases as residual nitrogen represent only a minor component of most foods. However, exceptions may include e.g. sorghum based foods, where a relatively big proportion ( $40-90 \%$ ) of the protein is found as residual nitrogen as compared to other cereals (10-20\%) (Bach Knudsen and Munck, 1985; Bach Knudsen et al., 1988). The determination of nitrogen in the residues is not an easy task as demonstrated in the first collaborative trial with the AOAC enzymatic-gravimetric method. The enormous variation in the TDF value for soya isolate could be attributed to variable residual nitrogen determination (Prosky et al., 1984). The same conclusion was drawn in the recent BCR Detailed Method Study for the determination of protein in blanks (Predlington and Brookes, 1995).

\section{Buffer}

The first intercollaborative trial with the AOAC method also identified too high final phosphate concentration, and hence variable ash content of the gravimetric residues as one of the underlying causes for the relatively poor reproducibility obtained in this study (Prosky et al., 1984). Reducing the 
phosphate concentration in the following study improved the performance of the method (Prosky et al., 1985). The replacement of the phosphate buffer with MES/TRIS buffer in the modified method of Lee et al. (1992) has further reduced this problem.

\section{Filtration and filter aid}

Filtration difficulties, in particular with viscous and desugared fruit samples, have frequently been encountered as a major problem influencing the general performance of the method. To avoid some of these difficulties, it is recommended to reduce portion size from 1.0 to $0.5-0.25 \mathrm{~g}$, which will reduce the filtration time to reasonable levels (Lee et al., 1992).

Improved performance of the enzymatic-gravimetric procedures can be obtained by standardising the type of celite used. In a survey among the participants in the AOAC/AACC 92 collaborative trial, it was reported that collaborators in research laboraties preferred to use Celite Analytical Filter $\Lambda$ id (CAFA), instead of Celite $545 \mathrm{AW}$, because CAFA allowed a minimum loss during filtration (Lee et al., 1992). However, most laboratories, in which a multitude of test samples were handled daily, supported the use of Celite 545 AW because of faster filtration rate as compared to that of CAFA. Filtration loss and incineration loss of crucibles are the most likely cause for the negative blank-ash values reported for IDF (19 out of 26) and in some cases for TDF, while only 3 out of 27 ash values were negative for the SDF blank determination (Prosky et al., 1992).

\section{Blanks and technical limitations of the gravimetric techniques}

All gravimetric techniques, because of the unspecificity, have limitations when applied to samples with low levels of dietary constituents (Faulks and Boenke, 1994). For the DF methods this is even more pronounced because a correction for blanks has to be applied. Moreover, the quantitatively smallest DF subfraction - soluble DF (SDF) - is the one with the largest and most variable blank value; the $5-95 \%$ SDF-blank fraction varies from 0.1 to 11.2 with a mean value of 5.95 (Table 2) (Prosky et al., 1992). Given these limitation, it is not surprising that all collaborative trials performed so far have shown far the biggest relative standard deviations for the SDF fraction.

\section{Collaborative trials}

The results obtained in the main collaborative trails with the enzymaticgravimetric AOAC methods are shown in Table 3. The method for TDF 
TABLE 2

Blank values (mg) obtained for total dietary fibre (TDF), soluble dietary fibre (SDF) and insoluble dietary libre (IDF)

\begin{tabular}{lrrr}
\hline & Mean & Range* $^{*}$ & Reference \\
\hline TDF-blanks & & & Faulks and Boenke (1994) \\
Protein & 19.67 & $3.8-28.6$ & \\
Ash & 1.65 & $-5.7-13.8$ & \\
Mean blank & 9.30 & $7.0-13.0$ & \\
SDF-blanks & & & Prosky et al. (1992) \\
$\quad$ Protein & 5.95 & $0.4-9.3$ & \\
Ash & 3.34 & $-4.7-7.9$ & \\
Mean blank & 5.95 & $0.1-11.2$ & \multirow{2}{*}{ Prosky et al. (1992) } \\
IDF-blanks & & & \\
Protein & 1.75 & $0.4-6.0$ & \\
Ash & -2.08 & $-11.3-2.1$ & \\
Mean blank & 1.44 & $-1.2-3.9$ & \\
\hline
\end{tabular}

*values for SDF- and IDF-blanks are 5-95\% intervals

determination was accepted as official AOAC method after two (AOAC 84 and AOAC 85) international collaborative trials (Prosky et al., 1984, 1985). The first inter-laboratory study, however, revealed big variations and poor repeatability $\left(r_{95}\right)$ and reproducibility $\left(R_{95}\right)$; the $R_{95}$ was in the range 1.7 to 21.2 giving a relative reproducibility standard deviation $\left(\mathrm{RSD}_{\mathrm{R}}\right)$ in the range 2.9 to $100.9 \%$. As indicated previously, three main problems were identified: too high final phosphate concentration and hence variable ash content of the gravimetric residues, problems with residual nitrogen determination and variable starch removal. Addressing these limitations in the second collaborative trial resulted in a significant improvement in reproducibility $\left(\mathrm{R}_{95} 0.8-3.8\right)$ and repeatability $\left(\mathrm{r}_{95}\right.$ 0.4-2.8) (Prosky et al., 1985). The collaborative study performed locally in Switzerland (Swiss 87 ) demonstrated even better reproducibilities with values in the range of 1.0 to 1.1 (Schweizer et al., 1988). The method for TDF is now approved the legal or recommended procedure for food analysis in the USA and several continental European countries.

The wish to validate a method for separate determinations of soluble and insoluble DF was studied in three AOAC and one Ministry of Agriculture, Fisheries and Food (MAFF) organised collaborative studies (Prosky et al., 1988, 1992, 1994; Wood et al., 1993). The result of the first AOAC collaborative trial (AOAC 88 ) was satisfactory with regard to the determination of TDF, and there was also a good agreement between the sum of IDF and SDF and the separate TDF determination (Prosky et al., 1988). The reproducibility of SDF, however, was unacceptably high. In a follow-up study (AOAC 92) comprising 22 samples, the $R_{95}$ of IDF ranged from 1.7 to 22.2 for the samples analysed; almost half the 
samples tested had a $\mathrm{RSD}_{\mathrm{R}}<10 \%$ (Prosky et al,, 1992). For SDF it was higher and approximately $50 \%$ of the samples analysed had an $\mathrm{RSD}_{\mathrm{R}}>20 \%$ and $45 \%$ had an $\mathrm{RSD}_{\mathrm{R}}$ between 10 and $20 \%$. In the most recent $A O A C$ collaborative trial (AOAC 94) comprising six samples, the average $\mathrm{R}_{95}$ of SDF was 2.52 (Prosky et al., 1994). However, in 4 of the 6 samples $\mathrm{RSD}_{\mathrm{R}}$ was lower than $10 \%$, while two samples with 1.21 and $4.13 \%$ SDF had $\mathrm{RSD}_{\mathrm{R}}$ of 28.28 and $24.12 \%$ RSDR respectively. Based on the last $A O A C$ collaborative trial, the enzymaticgravimetric method for the determination of SDF was adopted first action of AOAC International. In the MAFF IV study the $\mathrm{R}_{95}$ was higher with average values for SDF of 2.33; for IDF of 3.11 and of TDF of 5.34 (Wood et al., 1993).

Supplementation of the well known enzyme-neutral detergent fibre (NDF) procedure with an separate determination of SDF has been proposed to provide a practical method for rapid determination of TDF (Mongeau and Brassard, 1986, 1990). This method was tested in a collaborative trial in Canada (Canada 90 ), and claims to give values for NDF and soluble (SOL) DF in agreement with TDF obtained with the original enzymatic-gravimetric AOAC method. As shown in Table 3, the $\mathbf{R}_{95}$ and $r_{95}$ are satisfactory and comparable with the enzymatic-gravimetric AOAC procedure (Mongeau and Brassard, 1990). A major drawback with the method, however, is that the analysis of insoluble and soluble DF are performed on two different samples and under different solubilisation conditions. The risk is that some DF components are analysed twice or not at all.

Recently, a noncnzymatic-gravimetric method for determination of DF in products with little $(<2 \%)$ or no starch such as fruits, and vegetables and many purified polysaccharides were adopted first action by AOAC. The method gives comparable results to the enzymatic-gravimetric AOAC method $(\mathrm{Li}$ and Cardozo, 1994).

\section{ENZYMATIC-CHEMICAL METHODS}

The main characteristics of the most recent modifications of the enzymaticchemical Englyst and Uppsala methods are summarised in Table 4. In short the methods consist of the following steps: (a) weighing into a centrifuge tube, (b) solubilisation and removal of starch by specific enzymes, (c) precipitation of soluble polymers by $80 \%(\mathrm{v} / \mathrm{v})$ ethanol, (d) swelling of polysaccharides with 12 $\mathrm{mol} / \mathrm{I}$ of $\mathrm{H}_{2} \mathrm{SO}_{4}$ and hydrolysis of polysaccharides to monosaccharides with 0.4-2.0 mol/ $/ \mathrm{H}_{2} \mathrm{SO}_{4}$ and (e) end-point determination of neutral non-starch polysaccharide (NSP) residues by either GLC, HPLC or colorimetry and measurements of uronic acids by colorimetry.

The Uppsala method was published in 1979 and the Englyst method in 1982 (Theander and Åman, 1979; Englyst et al., 1982). The Uppsala method was 


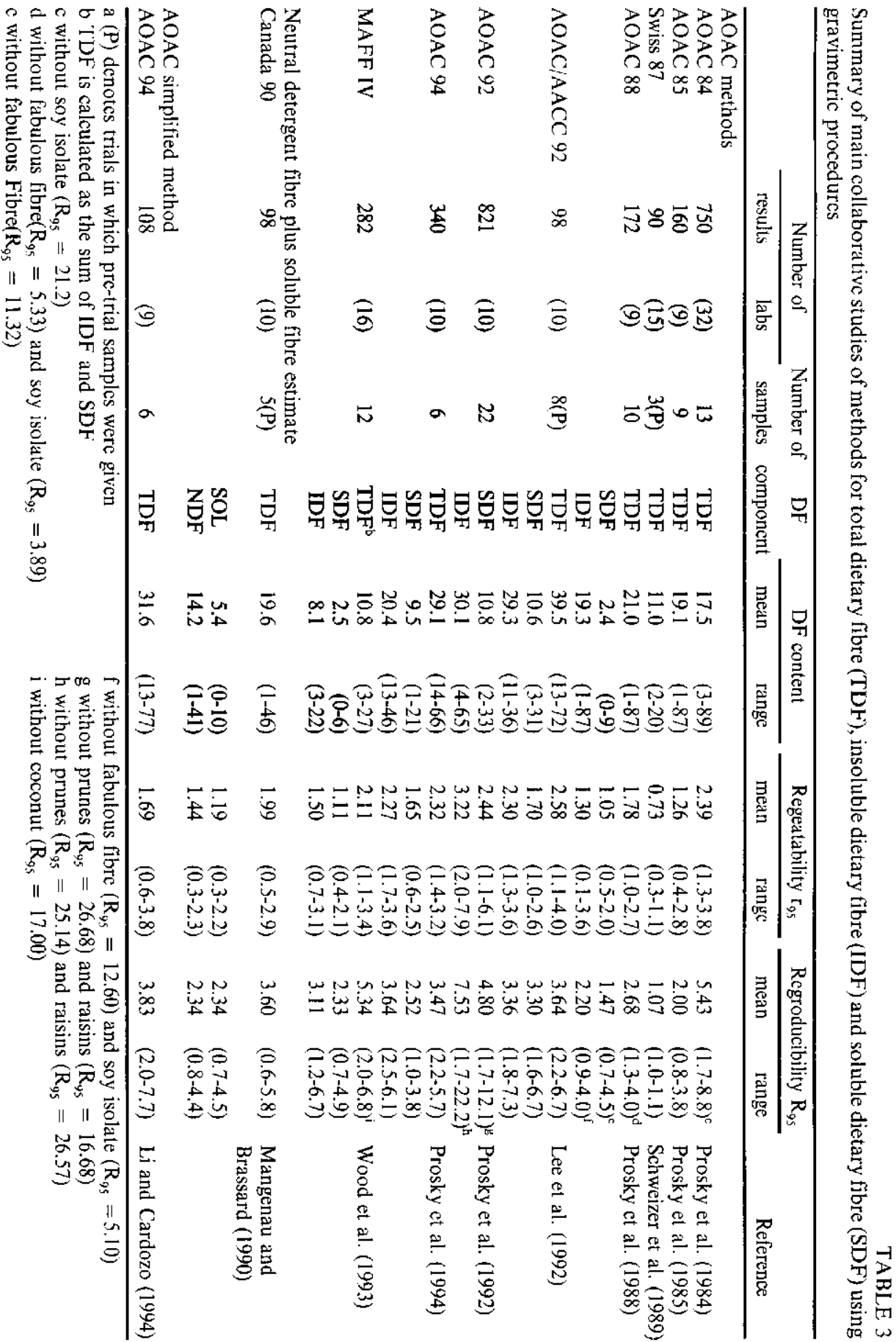




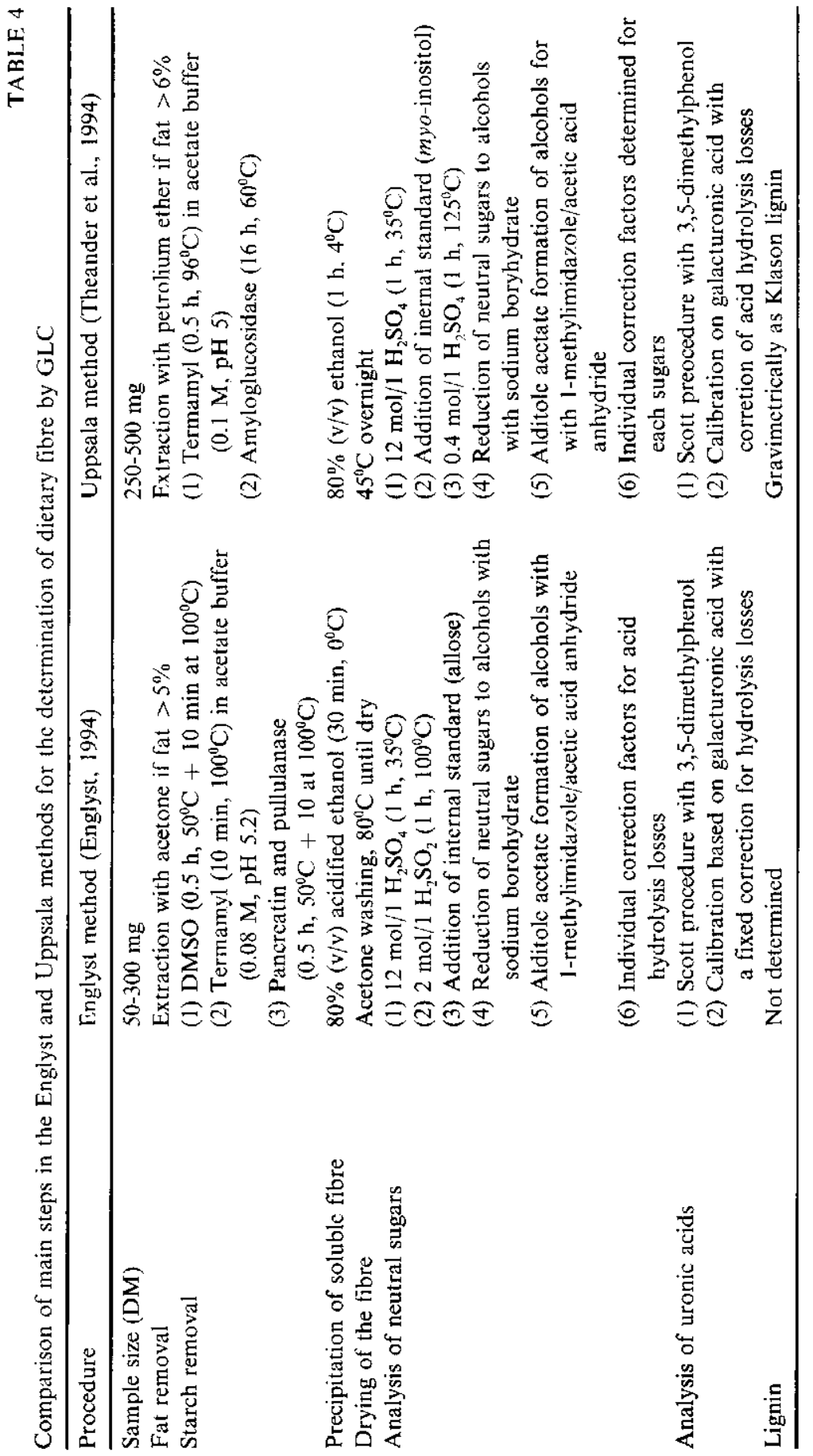


developed by workers whose primary interest was plant cell wall chemistry (Theander and Åman, 1979a), while the method of Englyst evolved within a nutritional research environment focussed on the measurement and characterisation of the carbohydrates in foods (Englyst et al., 1988, 1989) as well as understanding how the polysaccharides of plant cell walls in the food influence the physiology of the human gastrointestinal tract (Macfarlane and Cummings, 1991). Although a number of modifications have converged the methods, there are still differences of which the most important are: (a) the inclusion of the DMSO solubilisation step for "resistant starch" in the Englyst procedures, (b) the acid hydrolytic conditions, (c) the type of internal standard applied, (d) the compensation for hydrolytic losses and (c) the mcasurement of Klason lignin in the Uppsala method (Englyst et al., 1994; Theander et al., 1994).

\section{Starch removal}

The Uppsala and the Englyst methods use heat stable $\alpha$-amylase (Termamyl) to hydrolyse starch to malto-oligosaccharides but differ in the use of pancreatin and pullulanase (Englyst) and amyloglucosidase (Uppsala) to complete the degradation to glucose. The method of Englyst further includes a DMSO step to solubilise "resistant starch". It has been questioned if the DMSO treatment increases the solubility of DF components, since this reagent is used in structural analysis to solubilise hemicellulose polysaccharides. However, Englyst and Cummings (1984) did not found any differences in either cellulose or noncellulosic polysaccharides in samples treated with or without DMSO. It is also clear that DMSO treatment did not cause any loss of NSP as documented in the BCR Detailed Method Study and the BCR Reference Materials Study (Faulks and Boenke, 1994; Pendlington et al., 1996).

\section{Acid hydrolysis}

Acid hydrolysis of insoluble DF polysaccharides requires a two-step procedure involving dispersion of cellulose with $12 \mathrm{~mol} / 1$ of $\mathrm{H}_{2} \mathrm{SO}_{4}$ and hydrolysis with either $2 \mathrm{~mol} / \mathrm{l}$ of $\mathrm{H}_{2} \mathrm{SO}_{4}$ for $1 \mathrm{~h}$ at $100^{\circ} \mathrm{C}$ (Englyst) or $0.4 \mathrm{~mol} / 1$ of $\mathrm{H}_{2} \mathrm{SO}_{4}$ for $1 \mathrm{~h}$ at $125^{\circ} \mathrm{C}$ (Uppsala). The conditions chosen for the acid hydrolysis will inevitably be a compromise between the wish of obtaining maximal yield of sugars as well as minimal destruction of the released monosaccharides. The typical losses during acid hydrolysis (directly related to the treatment with acid or incomplete desulphation) are in the range of 4-11\% (Englyst et al., 1992). It is possible to account for hydrolysis losses by using corrections factors derived either from concomitant hydrolysis of reference sugar mixtures (Uppsala) or using fixed corrections factors (Englyst) (Theander and Westerlund, 1986; Englyst et al., 
1992). In the Uppsala procedure, the internal standard - myo-inositol - is added before the acid hydrolysis step, while the Englyst method adds the internal standard - D-allose - after completing the acid hydrolysis. Individual corrections for each sugars are used in both methods. However, when converting from mono- to polysaccharides the Englyst methods use a mean conversion factor of 0.89 , while the Uppsala method use 0.88 for pentoses and deoxyhexoses and 0.90 for other hexoses.

The uronic acids determination is a challenge in itself. In terms of specificity the decarboxylation method (Theander and Åman, 1979), originally used in the Uppsala procedure, has several advantages over the colorimetric procedures (Quigley and Englyst, 1994). However, because the equipment for performing the decarboxylation determination is not available in all laboratories, the colorimetric method of Scott, in spite of its limitations, is the procedure employed for uronic acid determination in both the Englyst and the Uppsala procedures (Englyst et al., 1994; Theander et al., 1995). The compensation for hydrolysis losses of uronic acids are done in different ways in the two methods. While the Uppsala method carry the uronic acid standards through the autoclaving procedure and further compensate for the lower degradation of oligomers than of monomers by a factor of 0.88 , the Englyst method use a fixed correction of the standard to compensate for the hydrolysis losses of uronic acids. The BCR Reference Matcrial Study did not show any significant differences between the two methods when analysing for uronic acids in ccreal samples with low levels of uronic acids (Pendlington and Brookes, 1995).

\section{End-point determination}

The end-point determination of sugars can optionally be performed by HPLC. The advantage of the HPLC procedure is avoiding the derivatisation step and the possibility of detecting any oligosaccharides deriving from incomplete hydrolysis of NSP. Recent progress in column technology and the introduction of the pulsed amperometric detection have made the HPLC technique more sensitive and specific. However, although HPLC has several theoretical advantages over GLC for the determination of sugar residues, HPLC is less frequently used as compared to GLC for end-point determination of sugar residues in DF analysis (Englyst et al., 1994). This is presumably due to the successful introduction of the 1-methylimidazole to catalyse the acetylation of sugar alcohols in DF analysis (Englyst and Cummings, 1984). Compared with previous techniques, the derivatisation has become much faster and easier and can be performed in the presence of borate without interference. Moreover, the GLC technique has the advantage over the HPLC technique that a chromatographic run is completed within $8-10 \mathrm{~min}$ as compared to $\sim 25 \mathrm{~min}$ for a HPLC run. 
Colorimetric assays are an alternative to GLC and HPLC determinations if only values for total NSP (or insoluble and soluble) are required. However, colorimetric methods have limitations. The method for measuring total reducing sugars by dinitrosalicyclic acid used by Englyst and Hudson (1987) exhibit different colour yields for pentoses, hexoses and uronic acids. The same is the case with para-hydroxy benzoic acid hydraside used by Faulks and Timms (1985). This may explain why some foods show differences in NSP values obtained by GLC or colorimetry in spite of an overall good correlation. Recent modifications of the dinitrosalicyclic acid assay have addressed some of these problems and corrected for the interferences from other food components of processed foods, and thereby made the procedure more robust (Englyst et al., 1994).

\section{Lignin determination}

Klason lignin, together with structural protein the non-carbohydrate part of the cell walls, is measured gravimetrically as the sulphuric acid resistant residue in the Uppsala method, but not by the Englyst method (Theander and Åman, 1979b; Theander and Westerlund, 1986; Englyst et al., 1992). In plant materials used for animal production lignin is an important dietary constituent with values in the range of $1-7 \%$ in whole grain cereals. Lower (flour $<1 \%$ ) and higher values (bran 7-15\%) may be found in cereal flour for human consumption or by-products for animal feeding (Bach Knudsen, 1997). It is argued that lignin, in human diets, represent only a small and therefore insignificant fraction. The physiological importance of lignin lies in the affect on the solubility of DF polysaccharides which has implications for the degradation of fibre in the large bowel of man and animals and consequently for the bulking properties and the energy values of the fibre. It should also be mentioned that Klason lignin, in addition to true lignin, also contain Maillard reaction products and degradation products formed as the result of heat processing (Theander et al., 1990).

\section{Collaborative trials}

The Englyst GLC and colorimetric procedures have been evaluated in four collaborative trials organised by the MAFF (Table 5). In the first study, MAFF I, five different methods were compared, but only the Englyst GLC method was selected for further studies (Cummings et al., 1985). In MAFF II seven breads were analysed by the GLC procedure, which showed acceptable repeatability but unsatisfactory reproducibility; the $\mathrm{R}_{95}$ was in the range of 3.7 to 8.7 corresponding to $\mathrm{RSD}_{\mathrm{R}}$ in the range of 29.9 to $59.5 \%$ (Englyst et al., 1987a). In MAFF III similar samples were analysed by an improved GLC procedure and by two 


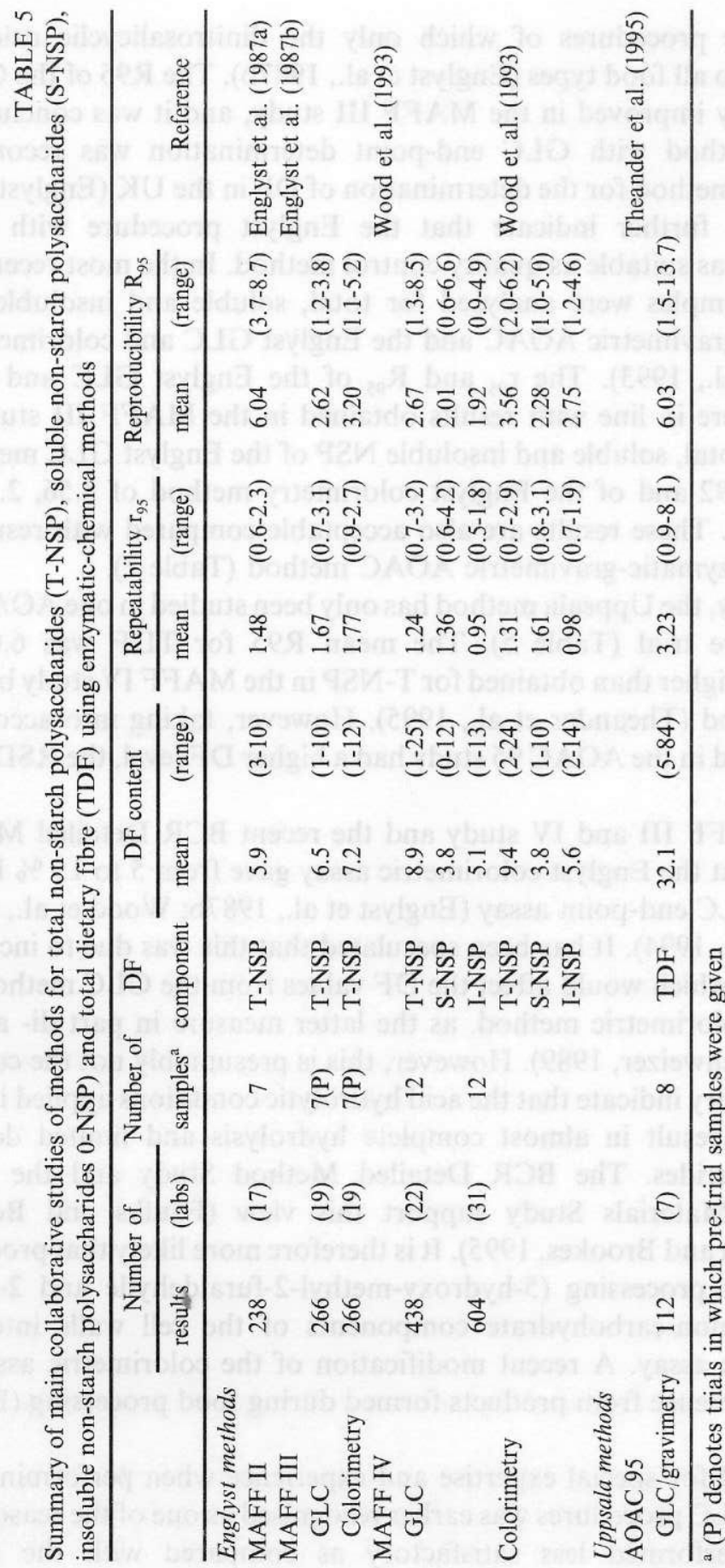


colorimetric procedures of which only the dinitrosalicyclic acid assay was applicable to all food types (Englyst et al., 1987b). The R95 of the GLC method was strongly improved in the MAFF III study, and it was concluded that the Englyst method with GLC end-point determination was recommended as a reference method for the determination of DF in the UK (Englyst et al., 1987). The results further indicate that the Englyst procedure with colorimetric end-point was suitable as quality control method. In the most recent MAFF IV study 12 samples were analysed for total, soluble and insoluble DF by the enzymatic-gravimetric AOAC and the Englyst GLC and colorimetric methods (Wood et al., 1993). The $r_{95}$ and $R_{95}$ of the Englyst GLC and colorimetric methods were in line with results obtained in the MAFF III study with R95 values for total, soluble and insoluble NSP of the Englyst GLC method of 2.67, 2.01 and 1.92 and of the Englyst colorimetry method of 3.56, 2.28 and 2.75, respectively. These results are also acceptable compared with results obtained with the enzymatic-gravimetric AOAC method (Table 2).

Currently, the Uppsala method has only been studied in one AOAC organised collaborative trial (Table 5). The mean R95 for TDF was 6.03, which is somewhat higher than obtained for T-NSP in the MAFF IV study by the Englyst GLC method (Theander et al., 1995). However, taking into account that the samples used in the $\Lambda O \Lambda C 95$ study had a higher DF level, the $\mathrm{RSD}_{R}$ were in the same order.

The MAFF III and IV study and the recent BCR Detailed Method Study revealed that the Englyst colorimetric assay gave from 5 to $15 \%$ higher values than the GLC end-point assay (Englyst et al., 1987b; Wood ct al., 1993; Faulks and Boenke, 1994). It has been speculated that this was due to incomplete acid hydrolysis, which would affect the DF values from the GLC method more than from the colorimetric method, as the latter measure in part di- and oligosaccharides (Schweizer, 1989). However, this is presumably not the case as tests in our laboratory indicate that the acid hydrolytic conditions applied in the Englyst procedures result in almost complete hydrolysis and limited destruction of monosaccharides. The BCR Detailed Method Study and the recent BCR Reference Materials Study support this view (Faulks and Boenke, 1994; Pendlington and Brookes, 1995). It is therefore more likely that products formed during heat processing (5-hydroxy-methyl-2-furaldehyde and 2-furaldehyde) and other non-carbohydrate components of the cell walls interfere in the colorimetric assay. A recent modification of the colorimetric assay claims to solve interference from products formed during food processing (Englyst et al., 1994).

The need for special expertise and experience when performing enzymaticchemical GLC procedures was earlier recognised as one of the reasons why these methods performed less satisfactory as compared with the more simple 
enzymatic-gravimetric procedures (Englyst et al., 1987a). As the laboratories participating in the collaborative trials have become more experienced, the reproducibility of the more complex enzymatic-chemical Englyst and the Uppsala methods has reached acceptable levels (Table 5). Moreover, the results of the BCR Reference Materials Study show that the coefficient of variation between laboratories in absolute terms are more or less at the same level for the AOAC enzymatic-gravimetric methods (original and modified), the Englyst GLC and colorimetric methods and the Uppsala method (Pendlington and Brookes, 1995).

\section{TECHNICAL PROBLEMS RELATED TO ALL METHODS}

\section{Enzymes}

A common feature of the enzymatic-gravimetric and enzymatic-chemical DF methods is the use of heat-stable $x$-amylase (Termamyl) to degrade starch to malto-oligosaccharides. It has been documented that the simultaneous gelatinisation and hydrolysis of starch at $100^{\circ} \mathrm{C}$ does not degrade fibre polysaccharides (Theander and Åman, 1979b). For complete hydrolysis of starch to glucose, the AOAC and the Uppsala procedures use various types of amyloglucosidases, while the Englyst methods use a combination of pancreatin and pullulanase. Unfortunately, many commercial amyloglucosidase preparations at present have side activities, e.g. $\beta$-glucanase and xylanase, which will result in depolymerisation of these fibre polysaccharides and potentially lead to lower values for the fibre contents in, for example, cereal samples (Theander et al, 1990). Consequently, it is important to check all enzyme batches for side activities prior to use in DF analysis.

\section{Alcohol strength}

Alcohol strength of around $80 \%(\mathrm{v} / \mathrm{v})$ is employed in all DF methods for the recovery of soluble polysaccharides and is generally considered sufficient to precipitate saccharides with a degree of polymerisation of 10 or more; i.e. the arbitrary defined borderline between oligo- and polysaccharides. However, highly branched polysaccharides, e.g. arabinans in sugar beet fibre, may be soluble even at significantly higher strengths of alcohol (Asp, 1990; Theander et al., 1990). In the BCR Detail Method Study, 2-4\% of the sugar residues in the polysaccharides mixture and $3-7 \%$ of the sugar residues in the sugar beet fibre were found to be soluble in $80 \%$ ethanol (Faulks and Boenke, 1994). These data are in accordance with studies conducted by Theander and Westerlund (1988), 
who found that the amount of soluble polysaccharides not recovered in $80 \%$ ethanol corresponded to $1-6 \%$ of the total fibre content of the original sample. The highest values were found in the most severely heat-treated samples (bread crust).

\section{INTERCOMPARISON STUDIES}

The number of controlled comparisons between methods is extremly limited. In general, however, the available data show that the AOAC and the Uppsala procedures give higher values for DF than those obtained by the Englyst procedures. This is seen of Table 6 that list DF values obtained by these methods in the most recent BCR Reference Materials Study (Pedlington et al, 1996). The reason for the discrepancies in DF values is primarily that the three procedures do not measure the same components. The AOAC (Asp et al. 1992) and the Uppsala procedures (Theander et al., 1994) are designed to measure total DF as NSP, resistant starch (retrograded amylose) and lignin, while the Englyst procedures (Englyst et al., 1994) are designed to measure all NSP constituents excluding any form of resistant starch. When correcting for resistant starch and lignin the AOAC, Uppsala and Englyst procedures gives identical mean values for the samples used in the intercomparison study of the recent BCR Reference Materials Study: white bread, whole wheat bread, a mixture of white and whole wheat bread and cornflakes (Pedlington and Brookes, 1995). The same factors also explain the differences between the values obtained for bran breakfast cereal and harricot beans, while for the pectin containing materials (carrot and apple), the differences between the methods are more difficult to explain. The very good agreement between all methods for full fat soya, however, is very encouraging.

\section{CHOICE OF ANALYTICAL METHOD}

The choice of analytical method depends primarily on the purpose of the analytical work (Southgate, 1995). This involves consideration of the criteria which the method and the values produced must meet to satisfy the needs of the analytical work. Since the performance of the DF methods after improvements is almost comparable (Tables 3, 5,6) the choice of method has to be set against the criteria determined by the purpose of the analysis (Table 7). While the methods are prescribed for analysts involved in analytical work of a regulatory kind, researcher can choose the methods giving the information that best suit the purpose of his work. Whereas a physiologist studying mechanisms may want to use a method providing detailed informations of the DF fractions, total DF may 


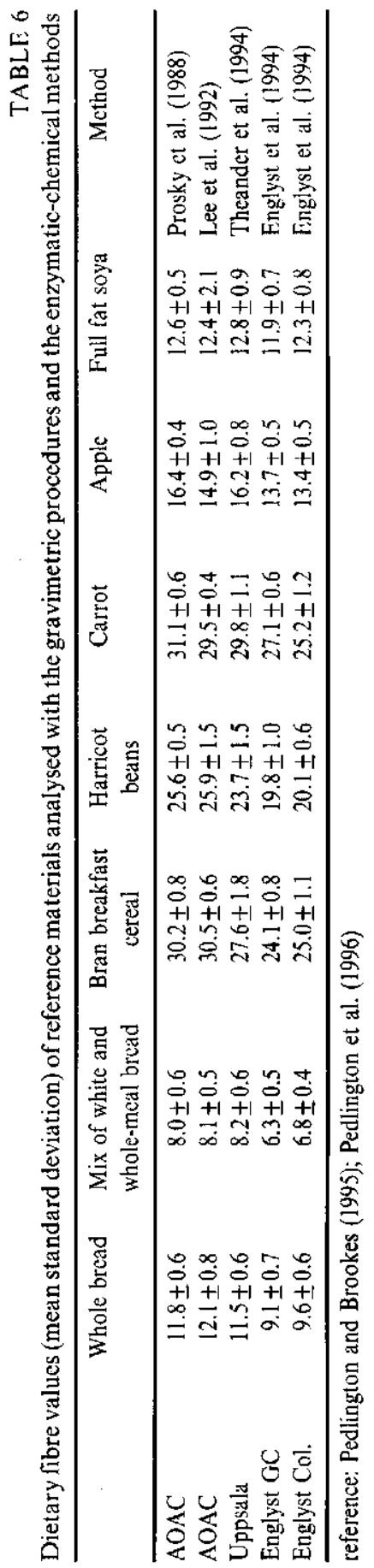


TABLE 7

Purposes for which dietary fibre is measured and the criteria which the analytical method has to meet

\begin{tabular}{|c|c|c|c|}
\hline Purpose & Charactcristics of a suitable method & Resource required & Time required \\
\hline $\begin{array}{l}\text { Research on } \\
\text { physiological } \\
\text { mechanism of } \\
\text { action }\end{array}$ & $\begin{array}{l}\text { Detailed characterisation of dietary } \\
\text { fibre. Flexible methods amenable } \\
\text { to expansion to give even grcater } \\
\text { detail }\end{array}$ & $\begin{array}{l}\text { Not critical; } \\
\text { outcomc most } \\
\text { important }\end{array}$ & $\begin{array}{l}\text { Not } \\
\text { critical }\end{array}$ \\
\hline $\begin{array}{l}\text { Nutritional } \\
\text { composition } \\
\text { data bases }\end{array}$ & $\begin{array}{l}\text { Nutritionally relevant to biological } \\
\text { role and to current nutritional } \\
\text { guidance. Compoartive with } \\
\text { labelling regulations }\end{array}$ & $\begin{array}{l}\text { Critical in relation } \\
\text { to work load }\end{array}$ & $\begin{array}{l}\text { Critical in relation } \\
\text { to costs }\end{array}$ \\
\hline Food labelling & $\begin{array}{l}\text { Defined, with good reproducibility. } \\
\text { Compatible with nutritional adcive } \\
\text { to consumer }\end{array}$ & Very critical & Very critical \\
\hline Food regulation & $\begin{array}{l}\text { Defined precise protocol. } \\
\text { Reproducible }\end{array}$ & Very critical & Very critical \\
\hline Quality control & $\begin{array}{l}\text { Simple emperical method. } \\
\text { Compatible with regulation. } \\
\text { Repedable, consistens performance } \\
\text { over long period }\end{array}$ & Very critical & Very critical \\
\hline
\end{tabular}

reference: Southgate (1995)

be enough when studying the variation in chemical composition of cereals as influenced by e.g. variety, location and year of harvest. In all case, however, the researcher needs to take into consideration whether resistant starch and lignin should be included in the DF value or measured separately from the NSP.

\section{CONCLUSIONS}

The enzymatic-gravimetric and the enzymatic-chemical techniques for the determination of DF in foods have progressed to a point where they are as reproducible as other analytical methods used for food and feed labelling and for research. The higher values obtained by the enzymatic-gravimetric AOAC methods and the Uppsala method as compared to the Englyst methods are primarily due to retrograded amylose (resistant starch) and lignin being included in the former methods. Accounting for these differences, the analytical methods give comparable results. 


\section{REFERENCES}

Asp N.-G., 1990. Delimitation problems in definition and analysis of dietary fiber. In: I. Furda, C.J. Brine (Editors). New developments in dietary fiber: Physiological, physiochemical, and analytical aspects. New York: Publishe, pp. 227-236

Asp N.-G., Schweizer T.F., Southgate D.A.T., Theander O., 1992. Dietary fibre analysis. In: T.F. Schweier, C.A Edwards (Editors). Dictary fiber - a component of food nutritional function in health and discase. Berlin: Publishe, pp. 57- 101

Bach Knudsen K.E., 1997. Carbohydrate and lignin contents of plant materials used in animal feeding. Anim. Feed Sci. Technol. (Accepted)

Bach Knudsen K.E., Kirlcis A.W.. Eggum B.O., Munck L., 1988. Carbohydrate composition and nutritional quality for rats of sorghum tó prepared from decorticated white and whole grain red flour. J. Nutr. $118,588-597$

Bach Knudsen K.E., Munck L., 1985. Dietary fibre contents and composition of sorghum and sorghum-based foods. J. Cereal Sci. 3, 153-164

Bailey R.W., Ulyatt M. J., 1970. Pasture quality and ruminant nutrition II. Carbohydrate and lignin composition of detergent extracted residues from pasture grasses and legumes. N.Z.J. Agric Res.13, 591-604

Carre B., Brillouet J.-M., 1986. Yield and composition of cell wall residucs isolated from various feedstuffs used for non-ruminant farm animals. J. Sci. Food Agric. 37, 341-351

Cummings J.H., Englyst H.N.. Wood R., 1985. Determination of dietary fibre in cereals and cereal products - collaborative trials. Part I : Initial trial. J. Assoc. Publ. Analysts 23,11323

Englyst H.H., Bingham S.A., Runswick S.A., Collinson E., Cummings J.H., 1988. Dictary fibre (non-starch polysaccharides) in fruit, vegetables and nuts. J. Hum. Nutr. Dict. 1, 247-286

Englyst H.N., Bingham S.A., Runswick S.A., Collinson E., Cummings J.H., 1989. Dietary fibre (non-starch polysaccharides) in cereal products. J. Hum. Nutr. Diet. 2, 253-271

Englyst H.N, Cummings J.H., 1984. Simplified method for the measurement of total non-starch polysaccharides by gas-liquid chromatography of constituent sugars as alditol acetates. Analyst $109,937-942$

Englysi II.N., Cummings J., Wood R., 1987a. Determination of dietary fibre in cereals and cereal products - collaborative trials. Part II: Study of a modified Englyst procedure. J. Assoc. Publ. Analysts 25, 59-71

Englyst H.N., Cummings J.H., Wood R., 1987b. Determination of dietary fibre in cereals and ccrcal products - collaborative trials. Part III: Study of further simplified procedures. J. Assoc. Publ. Analysts 25, 73-110

Englyst H.N., Hudson G. J., 1987. Colorimetric method for routine measurement of dietary fibre as non-starch polysaccharides. A comparison with gas-liquid chromatography. Food Chem. 24, 63-76

Englyst H.N., Quigley M.E., Hudson G.J., 1994. Determination of dietary fibre as non-starch polysaccharides with gas-liquid chromatography, high-performance liquid chromatography or spectrophotometric measurements of constituent sugars. Analyst 119, 1497-1509

Englyst H.N., Quigley M.E., Hudson G.J., Cummings J. H., 1992. Determination of dietary fibre as non-starch polysaccharides by gas-liquid chromatography. Analyst 117, 1707-1714

Englyst H., Wiggins H.S., Cummings J.H., 1982. Determination of the non- starch polysaccharides in plant foods by gas-liquid chromatography of constituent sugars as alditol acetatcs. Analyst 107, $307-318$

Faulks R.M., Boenke A., 1994. Dictary Fibre in Complex Food Materials. Detailed Method Study. European Commission Community Bureau of Reference: bcr information Chemical analysis EUR 15728 EN 
Faulks R.M., Timms S.B., 1985. A rapid method for determining the carbohydrate component of dietary fibre. Food Chem. 17, 273-287

Hellendoon E.W., Noordhoff M.G., Slagman J., 1975. Enzymatic determination of the indigestibie residuc (dietary fibre) content of human food. J. Sci. Food $\Lambda$ gric. 26, 1461-1468

Henneberg W., Stohmann F., 1859. Über das Erhaltungsfutter volljährigen Rindvichs. J. Landwirtsch. 3, 485-551

Lee S.C., Prosky L., De Vrics J.W., 1992. Determination of total, soluble, and insoluble dietary fiber in foods-cnzymatic-gravimetric method, MTS-TR IS buffer: Collaborative study. J. $\Lambda$ ssoc. Off. Agric. Chem. 75, 395-416

Li B.W., Cardozo M.S., 1994. Determination of total dictary fiber in foods and products with little or no starch, noncnzymatic-gravimetric method: Collaborative Study. J. Assoc. Off Agric. Chem. Int. $77,687-689$

Macfarlane G.T., Cummings J.H., 1991. The colonic flora, fermentation, and large bowel diestive function. In: S.F. Phillips, J. H. Pemberton, R.G. Shorter (Fditors). The large intestine: physiology, pathophysiology, and disease. New York: Publishe, pp. 51-92

Mongcau R., Brassard R., 1986. A rapid method for the determination of soluble and insoluble dietary fiber: comparison with AOAC total dietary fiber procedure and Englyst's method. J. Food Sci. 51, 1333-1336

Mongeau R., Brassard R., 1990. Determination of insoluble, soluble, and total dietary fiber: Collaborative study of rapid gravimetric method. Cereal Foods World 35, 319-324

Pendlington A.W., Brookes A., 1995. BCR studies in progress. In: K.E.B. Knudsen, H.N. Englyst, R.Gudmand-Høyer, $\Lambda$. Sørensen (Editors). Recent progress in the analysis of dietary fibre. Luxembourg, pp. 129-141

Pendlington A.W., Meuree-Vanlacthem N., Brookes A., 1996. The Method Specific Certification of the Mass Fraction of Dietary Fibre in Lyophilised I Iaricot Beans, Carrot, Apple, Full Fat Soya Flour and Bran Breakfast Cereal Reference Materials. European Commission Community Bureau of Reference: bcr information Chemical analysis EUR $17451 \mathrm{EN}$

Prosky L., Asp N.-G., Furda I., DeVrics J.W., Schweizer T.F., Harland B. F., 1984. Determination of total fiber in foods, food products, and total diets: Interlaboratory study. J. Assoc. Off. Agric. Chem. 67, 1044-1052

Prosky L., Asp N.-G., Furda I., DeVries J.W., Schweizcr T. F., Harland B. F., 1985. Determination of total dietary fiber in foods and food products: Collaborative study. J. Assoc. Off. Agric. Chem. 68, 677-679

Prosky L., Asp N.-G., Schwcizer T.F., DeVries J.W., Furda I., 1988. Determination of insoluble, soluble, and total dietary fiber in foods and food products: Interlaboratory study. J. Assoc. Off. Agric. Chem. 71, 1017-1023

Prosky L., Asp N.-G., Schwcizer T.F., DeVries, J.W., Furda I., 1992. Determination of insoluble and soluble dietary fiber in foods and food products: Collaborative study. J. Assoc. Off. Agric. Chem. Int. 75, 360-367

Prosky L., Asp N.-G., Schweizer T. F., DeVries J.W., Furda I., Lee S.C., 1994. Determination of soluble dietary fiber in foods and food products: Collaborative study. J. Assoc. Off. Agric. Chem. Int. 77, 690-694

Quiglcy M.E., Englyst H.N., 1994. Determination of the uronic constituents of non-starch poysaccharides by high-performance chromatography with pulsed amperometric detection. Analyst 119, 1511-1518

Reichert R.D., 1981. Quantitative isolation and estimation of cell wall materials from dehulled pea (Pisum satitum) flours and concentrates. Cereal Chem. 58, 266-270

Schweizer T.F., 1989. Dietary fibre analysis. Lebensm.-Wiss. -Technol. 22, 54-59

Schweizer T.F., Walter E., Venetz P., 1988. Ringversuch zur enzymatischgravimetrischen 
Bestimmung der Gesamtnahrungsfasern in Lebensmitteln. Mitt. Gebiete Lebensm. Hyg. 79, $57-68$

Southgate D.A.T., 1995. Dietary Fibre Analysis. In: RSC Food Analysis Monographs. Cambridge: The Royal Society of Chemistry

Theander O., Åman P., 1979a. The chemistry, morphology and anlysis of dietary fiber components. In: C. Inglett, I.Folkehag (Editors). Dictary fiber: chemistry and nutrition. New York and London, pp. 215-244

Theander O., $\Lambda$ man P., 1979b. Studies on dietary fibres. I. Analysis and chemical characterization of water-soluble and water-insoluble dietary fibres. Swedish J. Agric. Res. 9, 97-106

Thcander O., Aman P., 1980. Chemical composition of some forages and various residues from feeding value determinations. J. Sci. Food Agric 31, 31-37

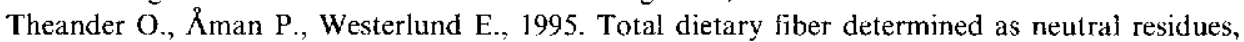
uronic acid residues, and Klason lignin (The Uppsala method): Collaborative study. J. Assoc. Off. Agric. Chem. Int. 78, 1030-1044

Theander O., Åman P., Westerlund E., Graham H., 1990. The Uppsala method or rapid analysis of total dietary tiber. In: I. Furda, C.J.Brine (Editors). New developments in dietary fiber: physiological, physiochemical, and analytical aspects. 270, 273-281

Theander O., Åman P., Westerlund E., Graham H., 1994. Enzymatic/chemical analysis of dietary fiber. J. Assoc. Off. Agric. Chem. Int. 77, 703-709

Theander O., Westerlund E., 1986. Studies in dietary fiber. 3. Improved procedures for analysis of dietary fiber. J. Agric. Food Chem. 34, 330-336

Theander O., Westerlund E., 1988. The effects on aqueous ethanol-soluble carbohydrates and protein in heat-processed whole grain wheat and white flour. J. Cereal Sci. 7, 145-152

Van Soest P.J., 1963. Use of detergents in the analysis of fibrous feeds. II. A rapid method for the determination of fiber and lignin. J. Assoc. Off. Agric. Chem. 46, 829-835

Van Soest P.J., Wine R.H., 1967. Use of detergents in the analysis of fibrous feeds. IV. Determination of plant cell-wall constituents. J. Assoc. Off. Agric. Chem. 50, 50-55

Williams R.D., Olmsted W.H., 1935. Biochemical method for determining indigestible residue (crude fibre) in feces; lignin, cellulose, and non-water solubic hemicelluloses. J. Biol. Chem.108, 653-666

Wood R., Englyst H.N., Southgate D.A.T., Cummings J.II., 1993. Determination of dietary fibre: Collaborative trials Part IV. J. Assoc. Off. Agric. Chem.. Publ. Analysts 29, 57-141

\section{STRESZCZENIE}

\section{Zalety i ograniczenia metod analizy włókna pokarmowego}

Istnieją dwa zasadnicze sposoby oznaczania włókna pokarmowego (DF) w żywności dla ludzi i paszach dla zwierząt, a mianowicie: enzymatyczna bądź nieenzymatyczna grawimetryčna metoda AOAC lub enzymatyczno-chemiczna Englyst'a i Uppsala. Głównymi czynnikami analitycznymi wpływającymi na przcbicg analizy metodą enzymatyczno-grawimetryczną są: zmienność stopnia usuwalności skrobi, zbyl wysokie stężenie końcowe buforu fosforanowego i spowodawana tym duża zmienność $w$ zawartości popiołu w masie końcowego produktu, zagadnienie sączenia lepkich i odcukrzonych prób owoców i wreszcie zmienna wartość prób ślepych. Standaryzacja i poprawki wprowadzane do metod grawimetrycznych poprawiły wyniki doprowadzajac do zadowalającego stopnia dokladności. Metody enzymatyczno-chemične z zastosowaniem chromalogralii cieczowo- 
-gazowej (GLC), wysokosprawnej chromatografii cieczowej (HPLC) lub kolorymetrii stosowane do końcowego pomiaru wartości sa zazwyczaj bardriej skomplikowane, wielostopniowe i wymagaja, w przypadku metod GLC I HPLC, bardziej zlożonej i nowoczesnej aparatury niż metoda grawimetryczna. Stopicń usunięcia skrobi, hydrolityczne warunki kwaśnej hydrolizy polisacharydów DF, poprawkowe współczynniki dotyczące strat hydrolitycznych cukrów i postępowanic laboratoryjne zotały uznane jako główne crynniki wplywające na odtwarzalność wyników stosowanymi metodami. Modyfikacje i optymalizacja pos\%czególnych etapów oraz ulepszenia techniczne w laboratoriach uczestniczących we wspólnych badaniach poprawily powtarzalność metod enzymatyczno-chemicznych do poziomu podobnego jaki uzyskiwany jest metodami enzymatycznograwimetrycznymi AOAC. Zagadnieniami technicznymi, którc mogą powodować błędy w oznaczaniu DF wszystkimi metodami są: niezupełne wytrącenie $80 \%(\mathrm{v} / \mathrm{v})$ etanolem. zanieczyszczenia bakteryjnymi amyloglukozydazami powodującymi depolimeryzację i potencjalne straty polisacharydów DF. Ostatnic badania z zastosowanicm prób referencyjnych (Reference Material Study) wskazują, że róźne metody dają porównywalne wyniki dla produktów zbożowych, gdy zastosuje siç poprawki na ligninę i na skrobię oporną na hydrolizę. To samo dotycry calych nasion soi.

W posumowaniu można stwierdzić, że metody oznaczania DF dają zadowalająco odtwarzalne wyniki podobnie jak inne metody analityczne stosowane do occny pasz i żywności oraz do cclów badawczych. 